\title{
The Politics of Innovation: Why innovations need a Godfather
}

\author{
D.J. Smith \\ Nottingham Trent University
}

\begin{abstract}
Innovation is closely linked to the development of technology. Hence it is often assumed that when an innovation fails it is the technology that is at fault. While this may be true in many instances, there are occasions when it is not the technology that is at fault, rather, it is managerial and organisational aspects that cause problems and lead to failure. Studies have shown that individuals who take on specific roles can play an important part in avoiding these problems. These roles include the technological gatekeeper, the product champion and the sponsor/coach. In addition to these roles, this paper argues that there is another, namely that of godfather. With this role a highly respected, senior figure within an organisation provides support that is critical in ensuring the project overcomes the hurdles that lie in the path of any major new development. The nature of the godfather role is explored through three case studies. These provide examples of the role and show how it can facilitate the innovation process.
\end{abstract}

Keywords: Innovation, management, roles, godfather, politics

Address for correspondence:

D.J. Smith

Nottingham Business School

Nottingham Trent University

Burton Street

Nottingham NG1 4BU

Tel. $\quad 00441158484745$

Fax. 00441158484707

Email David.Smith02@ntu.ac.uk 


\section{The Politics of Innovation: Why innovations need a Godfather}

\section{INTRODUCTION}

Why do organisations sometimes resist innovation? According to Schon (1963) it is because it leads to change. He pointed out that the novelty associated with innovation often challenges 'accepted ways of doing things and long established skills (Schon, 1963: p83). Frost and Egri (1991: p242) quoting Macchiavelli note that, 'the innovator makes enemies of all those who prospered under the old order'. Not only may working practices be affected, but the changes in technology that are typically part of innovation, often carry with them changes in social organisation that threaten established hierarchies. Hence innovation, where it takes places within organisations, may well have political consequences in that it brings about resistance; resistance that may threaten the project and even lead to it being abandoned.

Resistance to change is not the only political aspect of innovation. Maidique (1980), quoting Schwartz (1973), showed that the reluctance of middle managers to take risks, leads them to favour incremental innovations rather than radical ones. Further evidence of this has come in recent years from the work of Christensen (1997), who has shown how managers in established firms tend to favour incremental innovations when faced with disruptive technologies.

Another factor causing organisations to be resistant to innovation is the systems and procedures they employ, especially systems designed to provide for rational evaluation of new developments. In the 1960s Schon (1963: p83) noted how large companies employed formal screening committees, while 40 years later Howell et al. (2005: p660) described the same processes that they labelled 'approvals hurdles'. These systems form obstacles for innovation projects. They require future benefits to be quantified, but for new products and services this is difficult. Hence these systems can have a bias against innovation, because it can rarely provide the certainty they require.

Factors such as these give a political dimension to innovation. This, as Howell et al. (2005) note, makes the distribution of power and strategic actions important. The 
ability of a senior manager to exert power and influence can be crucial to the success of an innovation. It is the role of such individuals that this study focuses upon. In particular it explores the way in which senior managers exercise power and influence, usually in a subtle and even covert manner, in order to support innovation projects.

Metaphors are widely used in the social sciences, especially in marketing (Hunt and Menon, 1995) and organisation studies (Cornelissen, 2002), and have been used in connection with other roles associated with innovation (Afuah, 2003). Consequently this paper sets out to show that the metaphor of 'godfather' provides the most apt portrayal of this particular role.

\section{ROLES WITHIN THE INNOVATION PROCESS}

Schon (1963) was among the first to emphasize the human dimension of innovation. He observed that successful innovations involved a key role. He cited some fifteen major innovations where individuals played a pivotal part in the development process. Schon (1963: p77) used the metaphor of ‘champion’ to describe their role. Maidique (1980: p64) defines a product champion as,

\footnotetext{
'a member of an organisation who creates, defines and adopts an idea for a new technological innovation and who is willing to risk his or her position or prestige to make possible, the innovation's successful implementation'.
}

A key feature of the role is adopting the innovation, which means actively and enthusiastically promoting it as it progresses through the various stages of development (Howell et al., 2005). According to Schon (1963) promoting meant employing conviction, persistence and energy of the highest order (Howell et al., 2005). However product champions are typically more than simply enthusiastic promoters of an innovation. Frost and Egri (1991: p265) note that product champions have been shown to be 'particularly proficient' in terms of interpersonal skills. Not only are they willing to work with others, they are also politically astute (Chakrabarti, 1974) which makes them highly competent at galvanising internal support (Venkataraman, et al., 1992). This theme is taken up by Rogers (2003: p315) who describes product champions as 'brokers and arrangers'. 
The need for product champions is widely recognised (Kanter, 1988; Peters and Waterman, 1982; Pinchot, 1985), and their contribution to successful innovation has been widely reported (Frost and Egri, 1991; Howell and Higgins, 1990). Two thirds of the firms surveyed by Duchesneau (1977) confirmed the presence of such a role, and the SAPPHO project of the 1970s provided systematic evidence to support the product champion hypothesis (Achilladelis et al., 1971).

Throughout, it has been recognised that the product champion role is not a particularly senior one within an organisation. Rogers (2003) for instance suggests that product champions are typically middle managers. Nor is the product champion role usually a well defined position within the organisational hierarchy. Rather it is a role that individuals take on without the benefit of training and development.

Schon's seminal work in the 1960s acted as a catalyst (Maidique, 1980) that led in time to the identification of a number of other significant roles within the innovation process. Allen (1977), in a study of internal and external communications in R \& D laboratories, identified certain individuals as crucial to knowledge acquisition within the innovation process. Having identified that staff turnover and the employment of external consultants could make a modest contribution to external knowledge acquisition, Allen (1977: p145) found that there existed, 'a small number of key people to whom others frequently turned for information'. They were not part of a formal communications system, indeed Allen (1977: p161) stressed that much communication was informal. Termed 'gatekeepers' by Allen (1977), their role involved acting as, 'a clearing house for technical information for technologists' (Maidique, 1980: p62). They acquired and translated external technological knowledge and then disseminated it to colleagues within the organisation (Howell and Higgins, 1990: p318). Given the informal nature of much communication, gatekeepers used their extensive networks of personal communications both inside and outside the organisation to keep their colleagues informed.

As ideas about innovation, such as Cohen and Levinthal's (1990) theory of absorptive capacity, have increasingly come to recognise the importance of external and internal knowledge acquisition to successful innovation, especially in terms of distributing 
external information to appropriate colleagues within the organisation (Tushman and Nadler, 1986), so the importance of the gatekeeper role has been recognised.

Roberts (1968) was among the first to identify the value of innovations having some form of internal sponsor. In his terms sponsorship involved senior managers taking ‘supportive actions’ (Roberts (1968: p252) to assist more junior colleagues, particularly with the 'policies and attitudes' of large organisations which can impede the process of innovation. Frohman (1978), elaborated on the notion of support to suggest that the sponsor role involved senior managers 'coaching' subordinates. Coaching meant senior managers using their knowledge and experience to provide guidance and development opportunities for less experienced personnel. These types of activity could, according to Frohman (1978) help subordinates navigate their way through the bureaucracy of large organisations. Roberts and Fusfield (1981) in a study of R \& D laboratories suggested that the senior managers who could coach subordinates, were likely to be older, more experienced project leaders. Roberts and Fusfield stressed that the assistance was likely to be provided in a subtle and unrecognised way. Indeed they went on to caution against coaching being too directive, noting that with senior managers (Roberts and Fusfield, 1981: p254),

'coaching can degenerate into idea domination, project ownership and direction from the top.'

A slightly different perspective on the sponsor role comes from Maidique (1981). He portrays the sponsor as an 'executive champion', an entrepreneurial role that 'bridges the gap between the entrepreneur and the technological champion' (Maidique, 1981: p69). This implies a senior manager working closely with a product champion, who is likely to be a technological specialist, in order to provide him or her with support. This may well mean the sponsor using his or her technical expertise and the organisation's informal channels to gather information from technical staff. In this way a sponsor can counteract what Maidique (1981: p72) describes as the 'conservative bias' of middle management, resulting in hurdles being placed in the path of innovations that imply change. 
The idea of a senior manager providing sponsorship for innovations in the form of 'organizational protection' is also taken up by Leiffer et al. (2000: p162). All ten of the organisations that they studied benefited from a senior manager providing innovation projects with much needed organizational protection, resources and encouragement.

\section{METHODOLOGY}

This investigation of the nature of the godfather role is based on three case studies of well known innovations. Given that the role involves covert, 'behind-the-scenes' activities, the use of a survey, especially one based on self-administered questionnaires would be unlikely to uncover what Frost and Egri (1991: p244) describe as the 'political dynamics' that are an important part of the innovation process. Similarly, as the role is played out over time, the case for a longitudinal rather than a cross-sectional research design points to the use of case studies instead of some form of survey.

As the number of cases used in the study is small, the selection of innovations that form the basis of the study is clearly critical. The three chosen are all innovations that had a significant impact not just on the organisations that created them, but on the markets and industries in which they were located. The greater the significance of the innovation for the parent organisation, one might reasonably surmise the greater is the need for a godfather figure.

Two out of the three innovations had a wider impact on society, being variously described as a ‘cultural icon’ (Bardsley, 2005: p5) or ‘design icon’ (Laban, 1999, Setright, 1999), and even finding a place in the dictionary (Thompson, 1996). As a result there is a wide range of documentary material available that provides valuable insights into the innovation process in each instance. It includes a number of biographies of innovators (Bardsley, 2005; Nathan, 1999; Wood, 2005) and business histories (Jones, 2005; Sharratt, 2000; Whisler, 1999; Wyatt, 1980). Biographical material is used in many disciplines (Roberts, 2002) to explore a variety of aspects of people's lives. Although the use of biographical material is unusual in management research, Jones and Conway (2004) maintain that biographical research is a legitimate research approach in the study of innovation, and one that can provide a valuable 
source of qualitative data. When combined with contemporary press coverage, biographical material permits the construction of in-depth, longitudinal case studies that can be analysed to identify the key attributes of the godfather role.

\section{THE WALKMAN}

The Sony Walkman was the world's first portable stereo tape player. Introduced in July 1979, it proved to be a highly successful innovation. Not only did it sell in large numbers, with cumulative sales of 250 million units by 1998 (Nathan, 1999: p155), it transformed the audio equipment market. Its impact went beyond mere sales. The Sony Walkman made it possible to listen to one’s own choice of music virtually anywhere, including on the move. As Knight (1992) pointed out the Walkman changed the way we listen to music. So great has been its impact that it has become a 'cultural icon' - a symbol of late $20^{\text {th }}$ century society.

The story of how Sony developed the Walkman has been told many times and there are several different versions of what happened. In Stephen Bayley’s (BBC, 1991) words, 'a lot of benign myths' surround the innovation process. However all the accounts highlight the involvement of Sony chairman and co-founder, Akio Morita.

The origins of the Walkman lie in the late 1970s. By the end of the 1970s tape recorders, had evolved to the point where stereo cassette tape machines were firmly established in the audio equipment market. However truly portable units were rare and confined to monaural sound. Sony at this time was racking up losses on its Betamax video recording technology and its compact disc (CD) technology was not yet ready for the market (Nathan, 1999). Consequently in 1978 Sony chose to reorganise its activities and the tape recorder division lost its highly profitable radio cassette recorder work (BBC, 1991), which was transferred to another division. This put the division under intense pressure to come up with something else. Quite literally, 'the pride and honour of the tape recorder division depended on them coming up with a new product.' (BBC, 1991).The division's engineers tried modifying one of the company’s best-selling portable monaural tape recorders, the Pressman (du Gray et al. , 1997), to create a stereo machine. They discarded the speakers and the recording mechanism so that the machine consumed less power and ran on smaller batteries. This resulted in a smaller, lighter and more portable 
machine, but it required headphones to play pre-recorded music cassettes. The need for headphones combined with the machine's inability to record, led the division to conclude that the machine had no commercial potential (Nayak and Ketteringham, 1993). What was the use they reasoned of a tape recorder that could not record? This was reinforced by the fact that headphones were associated with deafness, a taboo subject in Japan (Nathan, 1999). Consequently the machine remained confined to the laboratory where young engineers used it to play music tapes while they worked.

No more would have been heard of this machine had not Masaru Ibuka, Sony's cofounder and honorary chairman, dropped in on the tape recorder division (Ueyama, 1997; Nathan, 1999; Nayak and Ketteringham, 1993). Ibuka was impressed by the quality of the sound. He had recently seen the prototype of a new set of lightweight headphones being developed by Sony’s Research Laboratory (Sanderson and Uzumeri, 1995). He insisted on combining the portable stereo tape player with the new headphones. The result was a lightweight machine ideal for listening to music on the move or while undertaking leisure activities. Having no executive responsibility Ibuka was not in a position to request the development of this hybrid product. Instead he called on Akio Morita, Sony's chairman.

From the start Morita was enthusiastic. He borrowed the machine for the weekend and took it with him when he played golf. He was convinced there was a market for the product among young people. At the following week's executive committee, Morita gained approval for the development of the new tape player (Nathan, 1999), but his enthusiasm was not shared by others. As he himself said, 'it seemed nobody liked the idea' (Morita et al., 1987: p80). The engineers were sceptical. Both the engineers from the tape recorder division and the engineers from the Research Laboratory were, 'polite but non-committal' (Nayak and Ketteringham, 1993: p98). As Nathan (1999: p152) in his study of Sony puts it, 'no one believed that a player with no capacity to record would catch on.' Worse still for the embattled tape recorder division, development of the new tape player was seen as, ‘a drain on the division’s money and manpower' (Nayak and Ketteringham, 1993: p100).

Approval for the development to proceed was granted in February 1979. Believing that the market for the new portable stereo tape player would be primarily amongst 
the young, especially students (Morita et al., 1997), Morita was adamant that the product be launched to coincide with the summer vacation (Kunkel, 1999). This was six months away and new products typically took two years to develop. A Walkman team was quickly assembled drawn from a range of functions (Ueyama, 1982). Given the timescale it was not possible to design and develop specific components, instead parts like the tape transport and the stereo circuitry were taken from other Sony products (Nathan, 1999). The first production run was optimistically set at 60,000 units at a time when Sony's most popular tape recorder was selling at the rate of 15,000 units a month (Nathan, 1999: p152). Kozo Ohsone, the head of the tape recorder division was so concerned that he bought parts for the projected number of units but planned for only half this level of production (Nayak and Ketteringham, 1993). However the team were well aware of Morita's faith in the product.

Sony's accountants showed a similar lack of enthusiasm for the project. This was particularly apparent when discussions took place to set the price. Initial estimates indicated a price of $\$ 249$ was needed to make a profit. Cost cutting reduced this to \$200 (Nayak and Ketteringham, 1993: p102), but Morita was unhappy, he wanted a lower price so that young people could afford it. Eventually the price was set at $\$ 165$, a price that had the company's accountants worried the device might not generate sufficient profit to recoup the costs of development (du Gay et al., 1997).

Like the company's engineers and accountants, when it came to the launch, the marketing staff too showed little enthusiasm for the Walkman. Morita (Morita et al., 1987: p81) in his memoirs claims the marketing people, ‘said it wouldn’t sell'. Nor were they alone, for when advance units were sent out they were greeted with scepticism by retailers who did not believe that a cassette recorder without a recording function would sell (Kunkel, 1999). For the first three months, it looked as if Morita's Sony colleagues were right, as Japanese teenagers failed to buy the product in anything like the numbers anticipated. But sales picked up in September. By the end of the month the first production run of 30,000 units had sold out (Sanderson and Uzumeri, 1995: p763) and Kozo Ohsone was in trouble because he hadn't built the other 30,000 units as projected. By early 1980 sales were running at 30,000 units per month as young urban professionals thronged to buy them having decided that the Walkman was a 'lifestyle’ product they had to have. As the idea took hold Sony found 
it had a runaway success on its hands. Production could not keep pace with demand as the first production model of the Walkman, the TPS-L2, sold 1.5 million units in the first two years (Sanderson and Uzumeri, 1995: p763). Sony’s competitors took a year to come up with a similar product, but by then the Walkman was well established enabling Sony to consistently retain a 50 per cent market share by revenue.

While accounts of the development of the Walkman vary over details, all highlight the prominent part played by Akio Morita. Just what was his role in the innovation? Given his enthusiasm for the device and that he was instrumental in setting up the Walkman project, there is a case for suggesting his role was that of product champion. However this fails to recognise that as the chairman of Sony, he was not directly involved in the development process. Rather accounts of Sony's innovations describe Morita as 'the father of the Walkman' (du Gay et al., 1997: p42), suggesting that his role was that of 'godfather'.

\section{THE MINI}

The Mini was the most successful car to be built in Britain. Over 5 million were built over a 41 year period (Wood, 2005: p171). During this time the design remained virtually unchanged. Yet when it was launched in 1959 it was 'revolutionary in concept' for a British car and 'bristled with ingenuity and innovation' (Wood, 2005: p167). The innovative nature of the Mini has been widely recognised (Whisler, 1999). Among the innovative features were:

- transverse engine and powertrain

- front wheel drive

- four wheel independent suspension

- new standards of manoeuvrability and road holding

Other cars had included some of these features, but none had included all of them and none had combined them in a car with an overall length of barely three metres.

Probably the most significant innovation was the product architecture that combined all these features together. This was to be the most influential part of the design, something that has been widely copied and is now reflected in the shape and structure of most volume built cars on the road today. The Mini was designed and built by what 
was then the British Motor Corporation (BMC). Its origins are to be found in the 1956 fuel crisis which led to petrol rationing in Britain. The introduction of petrol rationing brought a sharp drop in the demand for cars and increased the popularity of what were then known as 'bubble cars'. These were small, foreign built cars, usually powered by a motorcycle engine, that were lightweight and economical to operate.

Incensed by this market trend, late in 1956 Leonard Lord, the chairman and managing director of BMC, summoned car designer Alec Issigonis to his office. According to one recent biography (Bardsley, 2005: p188) Issigonis was told by Lord to abandon the medium sized car he was working on and 'design a proper small car to knock all those bloody bubble cars off the road'. Lord placed only one restriction on Issigonis. Because he wanted the new car to go into production 'really soon' (Pomeroy, 1964: p29), it had to use an engine that was already in production (Bardsley, 2005; Wood, 2005).

It was highly significant that the new project was commissioned personally by Leonard Lord. Lord had taken over the chairmanship of the British Motor Corporation (BMC) from Lord Nuffield two years earlier. A brilliant production engineer (Turner, 1979), he distrusted anything approaching sophistication in business, having no time for either salesmen or accountants (Wyatt, 1980). As head of Britain's largest car manufacturer, he was a powerful force within BMC. Key decisions covering capital expenditure, product strategy, product pricing and production plans were the responsibility of a Central Committee at BMC but Lord, 'frequently decided matters of pricing and product strategy without reference to the committee' (Whisler, 1999: $\mathrm{p} 47)$.

The fact that Issigonis had the full backing of Leonard Lord proved vital (Nahum, 2004). At the time the British car industry in general, and BMC in particular, was noted for producing very conventional designs. But Lord's backing allowed Issigonis to put forward a design that was radically different. In particular Issigonis was able to incorporate a number of innovations, such as front wheel drive and a transverse powertrain, that were particularly effective in addressing the problem of creating a small car that could seat four adults in comfort. 
In practical terms Lord's backing also affected Issigonis' s access to facilities. Bardsley (2005: p200) notes that,

'the key to delivering the project in three years was the priority access which the Issigonis cell [team] was granted to every single facility that Longbridge had to offer.'

At Lord's behest, Issigonis's team was allowed to go anywhere in the Longbridge plant and demand immediate attention. Nahum (2004: p55) notes that the team was given a priority number for parts manufacture. This meant that,

'...everything stopped when they saw that number on a drawing. The machine shop would make a part overnight, from a freehold sketch, if it was dimensioned.'

These practical examples show how Leonard Lord's influence supported the project team, granting them the highest priority when it came to accessing the company's resources. Without this the project would have been side-lined by the demands of routine manufacturing.

Development of the revolutionary new design was rapid. Within 120 days there were mock-ups of the new car (Pomeroy, 1964: p58). By October 1957 two prototypes were on the road as the first stage in an extensive test programme. In July 1958 little more than 18 months after the project had started, Lord himself drove the new car for the first time. After a five minute drive around the Longbridge site, he turned to Issigonis and said (Pomeroy, 1964: p51; Nahum, 2004: p57),

'Alec, this is it, I want it in production within twelve months.'

When Issigonis protested about the work that remained to be done, Lord replied (Pomeroy, 1964: p51),

'Don't worry about that; I shall sign the cheques, you get on with getting the thing to work.' 
At Lord's direction a new plant was built in Llanelli, to produce body panels for the new car, and there was a massive investment in new production facilities at Longbridge (Bardsley, 2005). The first production model came off the assembly line in April 1959 (Pomeroy, 1964: p65) and was introduced to the press in mid-August. A week later on $26^{\text {th }}$ August 1959 the car received its public launch. This was less than three years since the start of the project, a record time in which to develop a new car, especially one so different from the cars then in use. The planned level of production was a very ambitious 3000 cars per week.

Despite a high level of interest in the new car, sales initially faltered. Part of the problem was that early models encountered technical problems, one of the most publicised being a tendency for the car to fill with water when driven in wet conditions. These problems highlighted a negative aspect of a project that enjoyed Leonard Lord's patronage, namely that Issigonis and his small development team did not feel it necessary to fully evaluate all aspects of the design.

While sales of the Mini may have, 'quivered on the brink of failure in its first year of life' (Nahum, 2004: p59), as the new decade began, the new car caught on rapidly with more affluent and fashion conscious consumers. The Mini benefited from a host of celebrity owners. Sales rose sharply and the car quickly became a best seller. Production peaked in the mid-1970s when more than 300,000 per year were built (Golding, 1990: p220) and it remained in production until 2000. Such was its influence that over time almost every European and Japanese car manufacturer developed a small car employing the same innovative product architecture of front wheel drive and transverse powertrain.

\section{CLEARBLUE}

In the postwar years Unilever, aware that its principal products, detergents, soap and margarine, were all in mature markets, began to diversify. The diversification was based on a combination of innovation and acquisitions (Cox, Mowatt and Prevezer, 2003). The development of frozen food was an instance of the former, the company's expansion of its ice cream interests an instance of the latter. 
In pursuit of innovation Unilever also expanded its research function from the 1950s onwards. This reflected, 'a climate in which there were high expectations that research would lead to innovation and so provide a source of growth and new business' (Jones and Kraft, 2004: p106). Unilever's research effort tended to be incremental and lie within the company's core markets. As Jones and Kraft (2004:p107) note, 'Radical innovations remained unlikely not least because operating companies were usually not interested in developing and marketing concepts far beyond their existing product lines.' Unilever had a strong record of research, but it was a marketing-led company, where marketing and research were divorced from one another. The situation was not helped by Unilever's corporate culture which emphasized consensus rather risk taking.

Against this background, Unilever's success during the 1980s in developing a new medical diagnostic business stands in sharp contrast. The Clearblue pregnancy testing kit was a 'flagship product' (Jones and Kraft, 2004: p110) that enabled Unilever to enter an entirely new field, the 'over the counter' (OTC ) healthcare market using the fruits of its own research.

The origins of Clearblue went back to the immunological research undertaken at Unilever's Colworth laboratory in Bedfordshire, for the company's animal feeds division in the 1970s. Although this work led to a number of successful antibody products for livestock, the company failed to build on it. The Colworth laboratory was also active in helping its new medical division launch a number of diagnostic kits for use in hospitals and doctors' surgeries to identify bacterial infections. This led to a number of important patents being filed in the monoclonal antibodies (MCA) field. Despite the company's lead in immunology research, changes in company strategy in the early 1980s, meant that further innovations in this field looked unlikely.

However the company's Chemical Coordinator, T. Thomas, who was a member of Unilever's main board (Jones, 2005), recognised the potential of the company's science base. Following a visit to the Massachusetts Institute of Technology (MIT) he became convinced that Unilever should enter the medical diagnostics field. So it was that in 1982, Thomas with the strong support of Unilever's research director, Sir 
Geoffrey Allen, was able to convince the company to establish a new Medical Products Group (MPG) (Jones, 2005: p293). Allen and Thomas also persuaded the company's Special Committee to grant the MPG funds from Unilever's central resources in order to continue research, acknowledging that there would be losses as the unit built up its knowledge (Jones, 2005). The following year the MPG relaunched the medical diagnostics business as a separate company called Unipath. Unipath not only enjoyed a high degree of autonomy, it also enjoyed support at the highest levels within the company. Wary of entering the pharmaceutical field, Unilever's research director, strongly supported Unipath's focus on the growing overthe-counter (OTC) diagnostics market. It provided excellent scope for applying MPG's biotechnology expertise to diagnostic products for pregnancy testing, fertility status, and cholesterol and infectious disease status.

Strategy centred on achieving a significant innovation in a short space of time in order to ensure that MPG was not perceived internally as an expensive 'research boutique' (Jones and Kraft, 2004: p113). An OTC pregnancy test kit, derived from Unilever’s research into monoclonal antibodies and ready-to-use immunological reagents, quickly emerged as a potential 'flagship product' for Unipath. The Clearblue pregnancy test kit developed by Unipath, less than two years after MPG had been established, represented a significant advance on anything then on the market. Clearblue was more sensitive, faster and more reliable than any competing product. Particular attention was directed towards consumer feedback which identified problems in using existing products. The findings from consumer feedback were incorporated into the design process to yield not only a very effective but also a thoroughly user-friendly product. Unipath’s structure as a relatively small but independent unit made it possible to maintain close links between research and marketing. The science-led, but innovation-driven culture of Unipath facilitated the flow of information across the research/marketing interface. The strength of internal links permitted a rapid process of innovation. In this environment and given the relatively youthful nature of the enterprise, innovation was seen as a priority. In addition Unipath also benefited from having a culture that was both team oriented and outward looking, maintaining strong links with the external scientific community. This contrasted with the more cautious, consensus-building culture that was typical elsewhere in Unilever. 
Clearblue was launched in 1985 and was an immediate success. Within three months it had become the market leader in Britain with a one third share of the market. By 1988 Clearblue was generating an annual profit of $£ 8 \mathrm{~m}$. Further innovations followed. In the same year Clearblue One Stop was launched featuring a simplified and easier to use process. Other OTC diagnostic testing kits were developed including Clearplan launched in 1989, which tested for the onset of ovulation, and in the mid-1990s Clearview which tested for Chlamydia and Persona a fertility monitoring kit.

\section{CROSS CASE ANALYSIS}

All three of the cases cited are instances of radical innovation. The Walkman transformed the audio equipment market creating an entirely new type of product, the portable stereo tape player. The Mini not only created a new class of compact small car it created a new product architecture comprising front wheel drive and a transverse powertrain. That it has been copied by most other car manufacturers, is an indication of the significance of the design. Clearblue was not the first OTC pregnancy kit, but it was a significant advance on anything then on the market and set the standard as a user-friendly product. In addition it was a radical innovation for Unilever, being the company’s first OTC medical diagnostic product. Hence in all three cases the innovation in question was a significant one that transformed the business.

What is clear in all three of the cases is that the success of the innovation was closely linked to the actions of a senior executive. On the basis of the case studies the senior executives provided various forms of assistance, namely:

- Vision

- Credibility

- Protection

- Access to resources

Vision implies having the foresight to see the potential of a new product, service or process, in terms of as yet untapped markets and unknown consumers. Thus Akio 
Morita, from his knowledge of young people, or simply commercial intuition, could envisage a market for a new type of music player. Closely allied to this was the extraordinary faith that Morita had in his vision. This was critically important because, as the case indicates, this was something that Sony's engineers, accountants and marketing personnel did not share. Similarly Unilever benefited from T. Thomas's vision of the potential of medical diagnostics for the company, something inspired by his visits to MIT, and it was Leonard Lord's vision of a British small car to beat the so-called 'bubble cars' of the 1950s, that led to the Mini project.

The senior executives in these case studies also provided the respective projects with credibility. Given that all the innovations involved radical departures from existing products/technologies, they posed a challenge to internal vested interests. To counter the threat posed by these vested interests, all three innovations badly needed credibility. With powerful backers within their organisations, they gained credibility. That credibility was directly attributable to the support of senior executives. At Unilever Sir Geoffrey Allen, knighted for his contribution to science, was a respected scientist with an international reputation. At Sony, Akio Morita was virtually unique, not only was he the company chairman, and thus accorded much respect within the company hierarchy, he was also one of the company's co-founders. In addition he was no mean innovator himself having played a big part in the introduction of the transistor radio and the tape recorder. In the case of the Mini, Leonard Lord's credibility, certainly within the British car industry was undisputed in the 1950s when the car was being developed. Described as the most powerful man in the industry (Wood, 2005), when combined with his personal qualities which the same study described as, 'decisive, combative, ruthless and dictatorial' (Wood, 2005: p171), this meant that Leonard Lord was inclined to treat BMC as, 'his personal fiefdom' (Wood, 2005: p47). Consequently Issigonis and his small development team were in Bardsley’s (2005: p176) words,

'like an independent enclave operating in the grand principality of Longbridge under the protection of its overlord, Chairman Leonard Lord.'

The support provided by these senior executives is strongly linked to the protection it afforded the innovation and those developing it. In all three instances the project faced 
a potentially hostile culture within the parent organisation. In the case of the Mini, the culture within the British car industry was extremely conservative (Wood, 2005). British designs were not innovative. This was true of BMC and the Longbridge plant where the Mini was developed. According to Sharratt (2000: p179) in his history of the Longbridge plant, the Mini

'... couldn't have come from the existing team at Longbridge. Not in a hundred years.'

It was a similar story at Unilever. According to Jones and Kraft (2005: p107) Unilever had, 'a culture of caution'. This meant that innovation tended to be incremental and located within the company's core markets. This was a culture in which developments in new fields like medical diagnostics were not likely to be well received. Even Sony's culture, which was normally very receptive to innovation, was not ready for the Walkman. The problem is well illustrated by the language associated with the Walkman. Regarded as ‘heresy’ by Sony’s engineers (Nayak and Ketteringham, 1993: p100) and described as a 'dumb product' by Sony’s salesmen (Nayak and Ketteringham, 1993: p101), the Walkman was developed in a culture that was neither welcoming nor supportive. Under the circumstances the support of a senior executive was essential. Morita, Lord and Allen, were able to afford the respective innovations protection from a hostile culture. As the Walkman case illustrates, staff were willing to go along with the new development even though they doubted its value, because of respect for Akio Morita. It was a similar story in the other companies.

The three cases also point to the senior executives involved providing access to resources. Leonard Lord's ability to provide access to scarce resources was probably the most spectacular. He provided Issigonis and his small team with priority access to all the facilities that a large integrated car plant like Longbridge could offer. As Bardsley (2005: p200) notes,

'The key to delivering the product within three years was the priority access which the Issigonis cell [team] was granted to every single facility that Longbridge had to offer.' 
and again (Bardsley, 2005: p205),

'The support given by Leonard Lord was absolutely vital. He was the only person who could mobilize the factory 100 per cent behind the project which meant not just opening the doors of the experimental department but also allocating vast amounts of money to build the necessary facilities for manufacture.’

At Unilever, Sir Geoffrey Allen and T. Thomas secured additional financial resources for Unipath, in the form of a special allocation of funds from Unilever's central resources. At Sony, the resources provided by Akio Morita were less obvious. Given the very short development timescale, a lot of components were effectively cannibalised from existing products. However there was one important resource to which Akio Morita did provide access, namely headphone technology. This was vital in ensuring that the Walkman was a truly portable stereo tape player.

The case studies tell a consistent story in terms of the support provided for innovations by senior executives. Analysis of the cases also reveals another common theme. The cases show senior executives exercising power and influence indirectly. Morita at Sony, Lord at BMC, and Allen and Thomas at Unilever, all relied on 'behind-the-scenes' approaches to aid their respective innovations, rather than participating directly as a member of the development team. Hence a further attribute of this role, and one that differentiates it from other roles associated with innovation, is that it tends to be carried out in a discreet, even covert manner.

\section{CONCLUSION}

All three of the cases that form the basis of this study centre on radical innovations undertaken by large organisations. This is the kind of context in which one might expect innovation to have a political dimension. Innovation in any organisation tends to be accompanied by change. Where the innovation is radical rather than incremental, then the change is likely to be all the more significant as new technologies, new knowledge and new ways of working are introduced. These were exactly the types of change found in these three cases. Consequently they all involve 
situations where the political dynamics meant the project needed the kind of support that only a very senior figure within the organisation could provide.

Detailed analysis of the cases yields extensive evidence about the precise nature of the support provided. It is shown that the support took the form of vision, credibility, protection and access to resources. This kind of support was possible because of the individuals concerned. They were not merely senior executives. All three were major figures within their respective industries. They were highly respected, one might even say they were revered within their organisations. This enabled them to provide support without the need for direct involvement in the project. Instead they were able to rely on subtle, behind-the-scenes methods and this aspect is one of the defining aspects of the role.

The distinctive nature of the role and the subtleties surrounding the way in which it is carried out, makes it difficult to describe. In such situations metaphors can be helpful. The value of metaphors lies in their ability to transfer knowledge from a familiar domain to an unfamiliar one (Tsoukas, 1991). Widely used in both the physical sciences (Kaplan, 1964) and the social sciences (Hunt and Menon, 1995), they provide powerful insights that aid explanation and facilitate understanding. Where the roles associated with innovation are concerned, we have already seen that metaphors such as champion, gatekeeper and sponsor are used as explanatory devices to indicate the nature of each role. In this instance the metaphor of godfather appears to be the most appropriate.

The metaphor owes more to the American Mafia than the Christian tradition. Both imply some one who provides some form of protection. In the Christian tradition the godfather role involves spiritual guidance and protection for children. In the American Mafia it is physical protection derived from the reverence and respect accorded the godfather figure by the criminal community. However it is not just a matter of protection. Mafia godfathers, at least as portrayed in the media, are noted for using behind-the-scenes methods to achieve their ends.

There are a number of potential metaphors that could be used to describe the role. It has already been shown that the metaphor of sponsor covers some aspects, especially 
the provision of support in the form of financial assistance. Similarly one could use the metaphor of patron. A patron is a benefactor. Found especially in the arts, a patron is typically a wealthy individual who encourages and supports young artists. Neither of these metaphors however, expresses the way this role is carried out. Sponsors typically want to make much of their involvement, while the support of a patron, would normally be overt and probably widely publicised. The evidence of the case studies clearly shows senior executives not being directly involved in the innovation, but rather working behind-the-scenes in order to 'pull the various strings' (Tidd et al., 2005: p482), and ensure it succeeds. This dimension, combined with the protective aspect of the role and the respect and authority commanded by those who exercise it, suggests neither the sponsor nor the patron metaphors adequately conveys the nature of the role. It is precisely the covert, protective aspects of the role that the godfather metaphor confers.

Inevitably metaphors have their limitations. Firstly, metaphors by their nature are imprecise (Tsoukas, 1991). They rely for their power on their falseness and this inevitably means they do not exactly define the object in question. However the purpose of the paper is not to test or evaluate the role, but to identify and explore it and precision is therefore not critical. What is needed is something that is evocative, conveying the essential differentiating features of the role, which the godfather metaphor does very effectively. A second limitation is that individual metaphors tend to have a short life (Hunt and Menon, 1995). When first used a specific metaphor may indeed be fresh and incisive, but it loses its impact if used repeatedly. While the godfather metaphor has been used before in different contexts, it remains a powerful metaphor. It is not commonly used in management nor is it normally associated with innovation and technology, and it therefore retains its vitality and freshness. A third limitation is that metaphors are subject to what Black (1993: p20) refers to as metaphoric 'inflation', where metaphors in general are used so frequently that they loose their power. This may be true of some fields of management (Tsoukas, 1991) such as marketing. In the literature on innovation however, metaphors have been used more sparingly. True, metaphors have been used in connection with other roles associated with innovation, but if anything this provides a rationale for using a metaphor in this instance rather a deterrent. Their use in a similar context demonstrates their value in conveying the salient features of a role. 
Hence the case for using metaphors in general and the godfather metaphor in particular is strong. The evidence of the case studies points to a role in which powerful individuals all of whom are highly respected figures, use their influence to subtly guide innovation projects through the organisational hurdles that stand in their way. To describe this as a godfather role seems much the most appropriate metaphor. What is needed now is to flesh out more of the contexts in which the godfather role is significant. The paper shows that the role is a feature of radical innovations in large organisations, only further research will show whether it is more generally applicable. 


\section{REFERENCES}

Achilladelis, B., Jervis, P., Robertson, A., 1971. A Study of Success and Failure in Industrial Innovation, University of Sussex Press, Brighton.

Afuah, A., 2003. Innovation Management: Strategies, Implementation and Profits, $2^{\text {nd }}$ edition, Oxford University Press, Oxford.

Allen, T.J., 1977. Managing the Flow of Technology: Technology Transfer and the Dissemination of Technological Information within the R \& D Organisation, MIT Press, Cambridge, MA.

Bardsley, G., 2005. Issigonis: The Official Biography, Icon Books, Cambridge.

BBC, 1991. Design Classics: The Sony Walkman, BBC2 television series.

Black, M., 1993. More about Metaphor, in Ortony, A. (Ed.) Metaphor and Thought, $2^{\text {nd }}$ edition, Cambridge University Press, Cambridge, 18-41.

Chakrabarti, A.K., 1974. The role of champion in product innovation, California Management Review, 17 (2), 58-62.

Christensen, C.M., 1997. The Innovator's Dilemma: When New Technologies Cause Great Firms to Fail, Harvard University Business School Press, Boston, MA.

Cohen, W.M. and Levinthal, D.A, 1990 Absorptive Capacity: A New Perspective on Learning and Innovation, Administrative Science Quarterly, 35, 128-152.

Cornelissen, J.P., 2002. On the 'Organisational Identity' Metaphor, British Journal of Management, 13 (3), 259-268.

Cox, H., Mowatt, S., Prevezer, M., 2003. New Product Development and Product Supply within a Network Setting: The Chilled Ready-Meal Industry in the UK, Industry and Innovation 10 (2), 197-217.

du Gay, P., Hall, S., Janes, L., Mackay, H., Negus, K., 1997. Doing Cultural Studies: The Story of the Sony Walkman, Sage, London.

Duchesneau, T.D., Lafond, J.B., 1977. Characteristics of Users and Non-users of Innovation: The Role of Economical Organizational Factors, Annual Convention of the Eastern Economic Association, Hartford, Connecticut, April 1977.

Frohman, A.L., 1978. The Performance of Innovation: Managerial Roles, California Management Review, 20 (3), 5-12.

Frost, P.J., Egri, C.P., 1991. The Political Process of Innovation, in Cummings, L.L., Staw, B.M. (Eds.) Research in Organisational Behaviour, 13, JAI Press, Greenwich, CT, 229-295

Golding, R., 1990. Mini - Thirty Years On, $3^{\text {rd }}$ edition, Osprey Publishing, London. 
Howell, J.M., Higgins, C.A., 1990. Champions of Technological Innovation, Administrative Science Quarterly, 35, 317-341.

Howell, J.M., Shea, C.M., Higgins, C.A., 2005. Champions of product innovations: defining, developing, and validating a measure of champion behaviour, Journal of Business Venturing, 20, 641-661.

Hunt, S.D., Menon, A., 1995. Metaphors and Competitive Advantage: Evaluating the Use of Metaphors in Theories of Competitive Strategy, Journal of Business Research, 33, 81-90.

Jones, G., 2005. Renewing Unilever: Transformation and Tradition, Oxford University Press, Oxford.

Jones, G., Kraft, A., 2004. Corporate Venturing: The Origins of Unilever's Pregnancy Test, Business History, 46 (1), 100-122.

Jones, O., Conway, S., 2004. The international reach of entrepreneurial social networks: the case of James Dyson in the UK, in Etemad, H., (Ed.) International Entrepreneurship in Small and Medium-sized Enterprises: Orientation, Environment and Society, 3, McGill International Entrepreneurship Series, Edward Elgar, Cheltenham, 87-106.

Kanter, R.M., 1988 When a thousand flowers bloom: Structural, collective and social conditions for innovation in organisations, in Cummings, L.L., Staw, B.M. (Eds.) Research in Organisational Behaviour, 10, JAI Press, Greenwich, CT, 169-211.

Kaplan, A., 1964 The Conduct of Enquiry, Chandler Publishing, San Francisco.

Knight, J., 1992. The Walkman inventor is knighted, The Times, $5^{\text {th }}$ October 1992.

Kunkel, P., 1999. Digital Dreams: The Work of the Sony Design Center, Laurence King, London.

Laban, B., 2003. The Mini: The Making of a Modern Icon, Harper Collins, London.

Leifer, R., McDermott, C.M., O’Connor, G.C., Peters, L.S., Rice, M.P., Veryzer, R.W., 2000. Radical Innovation: How Mature Companies Can Outsmart Upstarts, Harvard Business School Press, Boston, MA.

Maidique, M.A., 1980. Entrepreneurs, Champions and Technological Innovation, Sloan Management Review, Winter 1980, 59-76

Morita, A, Reingold, E.M., Shimomura, M., 1987. Made in Japan: Akio Morita and Sony, Collins, London.

Nahum, A., 2004. Issigonis and the Mini, Icon Books, Cambridge.

Nathan, J., 1999. Sony: The Private Life, Houghton Mifflin, NY. 
Nayak, R.N., Ketteringham, J.M., 1993. Breakthroughs! How Leadership and Drive Create Commercial Innovations that Sweep the World, Mercury Business Books, Didcot.

Peters, T.J., Waterman, R.M., 1982. In search of excellence, Harper and Row, NY.

Pinchot, J. III, 1985. Intrapreneuring, Harper and Row, NY.

Pomeroy, L., 1964. The Mini Story, Temple Press Books, London.

Roberts, B., 2002. Biographical Research, Open University Press, Buckingham.

Roberts, E.B., 1968. Entrepreneurship and Technology, Research Management, 11 (4), 249-266.

Roberts, E.B., Fusfield, A.R., 1981. Staffing the Innovative Technology-Based Organization, Sloan Management Review, Spring 1981, 19-33.

Rogers, E.M., 2003. Diffusion of Innovations, $5^{\text {th }}$ edition, The Free Press, New York.

Sanderson, S., Uzumeri, M., 1995. Managing Product Families: The case of the Sony Walkman, Research Policy, 24, 761-782

Schon, D.A., 1963. Champions of Radical New Inventions, Harvard Business Review, 41, March-April 1963, 77-86.

Setright, L.J.K., 1999. Mini: the design icon of a generation, Virgin Publishing, London.

Sharratt, B., 2000. Men and Motors of the 'The Austin': The inside story of a century of car making at Longbridge, Haynes Publishing, Sparkford.

Schwartz, J.S., 1973. The Decision to Innovate, DBA dissertation, Harvard University Graduate School of Business Administration, Boston, MA.

Thompson, D., 1996. The Oxford Compact English Dictionary, Oxford University Press, Oxford.

Tidd, J., Bessant, J., Pavitt, K. , 2005. Managing Innovation: Integrating Technological, Market and Organisational Change, $3^{\text {rd }}$ edition, John Wiley and Sons, Chichester.

Tsoukas, H., 1991 The Missing Link: A Transformational View of Metaphors in Organisational Science, Academy of Management Review, 16 (3), 566-585.

Turner, G., 1971. The Leyland Papers, Eyre and Spottiswoode, London.

Tushman, M., Nadler, D., 1986. Organizing for Innovation, California Management Review, 28 (3), Spring 1986, 74-92. 
Ueyama, S., 1982. The selling of the Walkman, Advertising Age, $22^{\text {nd }}$ March 1982.

Venkataraman, S., MacMillan, I.C., McGrath, RG.., 1992. Progress in research in corporate venturing, in Sexton, D.L., Kasarda, J.D., (Eds.) The State of the Art of Entrepreneurship, PWS-Kent Publishing, Boston, MA, 487-519.

Whisler, T.R., 1999. The British Motor Industry 1945-94: A Case Study in Industrial Decline, Oxford University Press, Oxford.

Wood, J., 2005. Issigonis: The Man Who Made the Mini, Breedon Books, Derby.

Wyatt, R.J., 1980. The Austin 1905-1952, David and Charles, Newton Abbott.

DJS/The Politics of Innovation_v1.3/17 March 2006 